\title{
Economical Feasibility of Utilizing Photovoltaics for Water Pumping in Saudi Arabia
}

\author{
Ahmet Z. Sahin ${ }^{1}$ and Shafiqur Rehman ${ }^{2}$ \\ ${ }^{1}$ Department of Mechanical Engineering, King Fahd University of Petroleum and Minerals, Dhahran 31261, Saudi Arabia \\ ${ }^{2}$ Center for Engineering Research, Research Institute, King Fahd University of Petroleum and Minerals, \\ Dhahran 31261, Saudi Arabia
}

Correspondence should be addressed to Ahmet Z. Sahin, azsahin@gmail.com

Received 15 June 2012; Revised 3 September 2012; Accepted 4 September 2012

Academic Editor: Daniel Chemisana Villegas

Copyright ( 2012 A. Z. Sahin and S. Rehman. This is an open access article distributed under the Creative Commons Attribution License, which permits unrestricted use, distribution, and reproduction in any medium, provided the original work is properly cited.

Energy and water are the two major need of the globe which need to be addressed for the sustenance of the human beings on this planet. All the nations, no matter most populous, developed and developing need to diversify the means and ways of producing energy and at the same time guarding the environment. This study aims at techno economical feasibility of producing energy using PV solar panels and utilizing it to pump-water at Dhahran, Riyadh, Jeddah, Guriat, and Nejran regions in Saudi Arabia. The solar radiation data from these stations was used to generate electricity using PV panels of $9.99 \mathrm{~kW}$ total capacity. Nejran region was found to be most economical in terms of minimal payback period and cost of energy and maximum internal rate of return whereas PV power production was concerned. Water-pumping capacity of the solar PV energy system was calculated at five locations based on the PV power production and Goulds model 45J series of pumps. Monthly total and annual total water pumping capacities were determined. Considering the capital cost of combined solar PV energy system and the pump unit a cost analysis of water pumping for a well of $50 \mathrm{~m}$ total dynamic head (TDH) was carried out. The cost of water pumping was found to vary between 2 and $3 \mathrm{US} \pitchfork / \mathrm{m}^{3}$.

\section{Introduction}

Solar energy is a clean source of energy, and it does not risk human lives, environment, and economic disasters which may include oil and coal sludge spills, coal mine and devastating gas pipeline explosions, unforeseen nuclear accidents, and water supply contamination from natural gas fracking. Its utilization promotes better health through decreased coal plant emissions pollution.

Water pumps, powered by photovoltaic (PV) panels, are being used frequently to pump water for domestic usage, to irrigate crops and landscape, to cattle, and provide potable water. The advantage of using solar energy for pumping the water is that major quantities of water are required during day time and that too during time when the sun is on top of our head, and during these times the PV panels produce maximum energy and hence the water quantity. These solar pumps can be installed anywhere no matter it is a valley, remotely located farms, forest, or locations which are difficult to reach and are not connected to national electric grid. The utilization of solar water pump in developing countries is providing a workable solution to meet water needs of the people. At the same time, one can also save the environment by avoiding or minimizing the burning of fossil fuel for energy generation. The solar water-pumping technology is commercially available, has-proven record of reliability, require, minimal skilled manpower once in operation, and operation and maintenance cost is also very minimal and affordable.

Kingdom of Saudi Arabia is blessed with high intensities of solar radiations and longer durations of sunshine hours and vast open land with gentle topographical features in most of it and complex terrain in some part of it. According, Rehman et al. [1] global solar radiation varies between a minimum of $1.63 \mathrm{MWh} / \mathrm{m}^{2} / \mathrm{y}$ at Tabuk and a maximum of $2.56 \mathrm{MWh} / \mathrm{m}^{2} / \mathrm{y}$ at Bisha while mean value remained as 
$2.06 \mathrm{MWh} / \mathrm{m}^{2} / \mathrm{y}$. The sunshine duration varied between 7.4 and $9.4 \mathrm{~h}$ with an overall mean of $8.89 \mathrm{~h}$ or about a total of $3245 \mathrm{~h}$ in a year. The specific yield was found to vary from 211.5 to $319.0 \mathrm{kWh} / \mathrm{m}^{2}$ with a mean of $260.83 \mathrm{kWh} / \mathrm{m}^{2}$ [1]. The dwellings are spread all over the Kingdom with major concentrations in Dhahran on the eastern coast, Riyadh in the central part, Jeddah on the west coast, Guriat in the north most, and Nejran in the south part. Most of the major cities are connected to national electricity grid and the network of national and provincial highways. Still there are remote areas and smaller cities and towns which are not yet connected to national electricity grid and are dependent on power supply from diesel generating power stations and have isolated grids. Some of these dwellings are located in mountainous region where it is not only difficult to lay the grid but also economically prohibitive. Availability of water for domestic use and drinking purposes is a great challenge in such areas and areas which are far from the main cities or industrial regions. Ground water is available in most of these areas but they require electricity and equipment to pump the water for domestic usage, irrigation, and cattle.

Water pumping has regularly been a technical challenge, solving the problems of drinking water supply and regular irrigation was a prerequisite for the development of civilization in many of the ancient empires [2]. The PVPSs are being installed worldwide, and there were approximately 10,000 such systems in 1993 which reached to almost six time that is, 60,000 units in 1998, [3]. The ongoing efforts on performance improvement and modeling [4-9], system sizing and optimization [10-14], and performance of PV systems [15] on the basis of experimental measurements have resulted in commercially acceptable, economically affordable, and easily maintainable with least possible expertise. These developments have lead and are contributing to the improvement of the lives of remotely located dwellings.

J. S. Ramos and H. M. Ramos [16] used a pump of $154 \mathrm{~W}$ powered by a solar array of 195 watt peak $\left(W_{p}\right)$ to pump water for village having ten families and consuming $100 \mathrm{~L}$ of water each with 6 -day immunity period and $2 \%$ permissible loss of load at a cost of $1.06 € / \mathrm{m}^{3}$ and capital investment of $3019 €$. Ould-Amrouche et al. [17] stated that the utilization of PV water-pumping systems helped both in improving the living conditions in remote areas and keeping the environment clean. Mahmoud and ElNather [18] conducted the economical feasibility of using photovoltaic (PV) technology to pump the ground water in comparison with using diesel units. Their study proved that PV-battery system was economical compared to the diesel system. According to Kaldellis [19] the PV waterpumping systems (PVPSs) are environmentally friendly solution and contribute substantially to the satisfaction of remote communities' water consumption needs.

PV-powered water-pumping systems have been installed and are operational in various parts of the globe including Arabian countries, and some of these installation dates back to early 1990s. Some of these studies and installations have been reported in the literature like Bhave [20] for India, Alawaji et al. [21] for the Kingdom of Saudi Arabia, Hammad [22] for Jordan, Al Suleimani and Rao [23]
TABLE 1: Geographical coordinates of meteorological stations considered in this study.

\begin{tabular}{lccc}
\hline Location & Latitude, $\left({ }^{\circ} \mathrm{N}\right)$ & Longitude, $\left({ }^{\circ} \mathrm{E}\right)$ & Elevation, $(\mathrm{m})$ \\
\hline Dhahran & 26.3 & 50.2 & 17 \\
Riyadh & 24.7 & 46.7 & 620 \\
Jeddah & 21.7 & 39.2 & 17 \\
Guriat & 31.4 & 37.7 & 504 \\
Nejran & 17.6 & 44.4 & 1212 \\
\hline
\end{tabular}

TABLE 2: Global solar radiation on horizontal surface $\left(\mathrm{kWh} / \mathrm{m}^{2} / \mathrm{d}\right)$.

\begin{tabular}{lccccc}
\hline Month & Dhahran & Riyadh & Jeddah & Guriat & Nejran \\
\hline Jan & 3.57 & 3.76 & 4.53 & 3.14 & 5.71 \\
Feb & 4.42 & 4.63 & 5.32 & 3.96 & 6.60 \\
Mar & 5.13 & 5.38 & 6.18 & 5.04 & 6.98 \\
Apr & 6.03 & 6.19 & 6.88 & 6.15 & 7.43 \\
May & 7.03 & 7.15 & 7.17 & 7.10 & 7.65 \\
Jun & 7.73 & 7.87 & 7.12 & 7.95 & 7.87 \\
Jul & 7.26 & 7.59 & 7.04 & 7.76 & 7.22 \\
Aug & 6.97 & 7.15 & 6.53 & 6.92 & 7.14 \\
Sep & 6.45 & 6.34 & 6.17 & 5.92 & 7.53 \\
Oct & 5.33 & 5.47 & 5.56 & 4.41 & 7.09 \\
Nov & 4.00 & 4.22 & 4.60 & 3.26 & 6.37 \\
Dec & 3.28 & 3.52 & 4.15 & 2.80 & 5.65 \\
\hline Annual & $\mathbf{5 . 6 0}$ & $\mathbf{5 . 7 8}$ & $\mathbf{5 . 9 4}$ & $\mathbf{5 . 3 7}$ & $\mathbf{6 . 9 4}$ \\
\hline
\end{tabular}

for Oman, Al-Karaghouli and Al-Sabounchi [24] for Iraq, Manolakoset al. [25] for Greece, Kordab [26] for ESCWA member countries, Meah et al. [27] for, Sutthivirode et al. [28] for Thailand, and Chueco-Fernández and Bayod-Rújula [29] for Chile. In Saudi Arabia, the work has been reported on various aspects of solar energy such as radiation data prediction and estimation [30-37], photovoltaic-based cost of solar energy by generation Rehman et al. [38], availability of solar radiation and sunshine duration by Aksakal and Rehman [39], photovoltaic electricity for irrigation Rehman et al. [40] desert camping Al-Ali et al. [41], and solar radiation and sunshine duration maps by Mohandes and Rehman [42].

\section{Input Data and Assumptions}

The geographical coordinates and elevation above mean sea level of all the locations being considered in the present work are listed in Table 1. The global solar radiation values are summarized in Table 2 for Dhahran, Riyadh, Jeddah, Guriat, and Nejran. The isolated grid PV power system with $9.99 \mathrm{~kW}$ of installed capacity is considered for all the locations being reported in this paper. The PV systems consist of 54 modules of $185 \mathrm{~W}$ each with rated efficiency of $14.8 \%$, module frame area of $1.24 \mathrm{~m}^{2}$, nominal operating cell temperature of $45^{\circ} \mathrm{C}$, temperature coefficient of $0.40 \%$, and an inverter of $10 \mathrm{~kW}$ capacity with $90 \%$ efficiency. The miscellaneous losses in energy yield process are taken as $1 \%$. For financial analysis, the capital cost is taken as 8US\$ per $W_{p}$ with 25 years of 


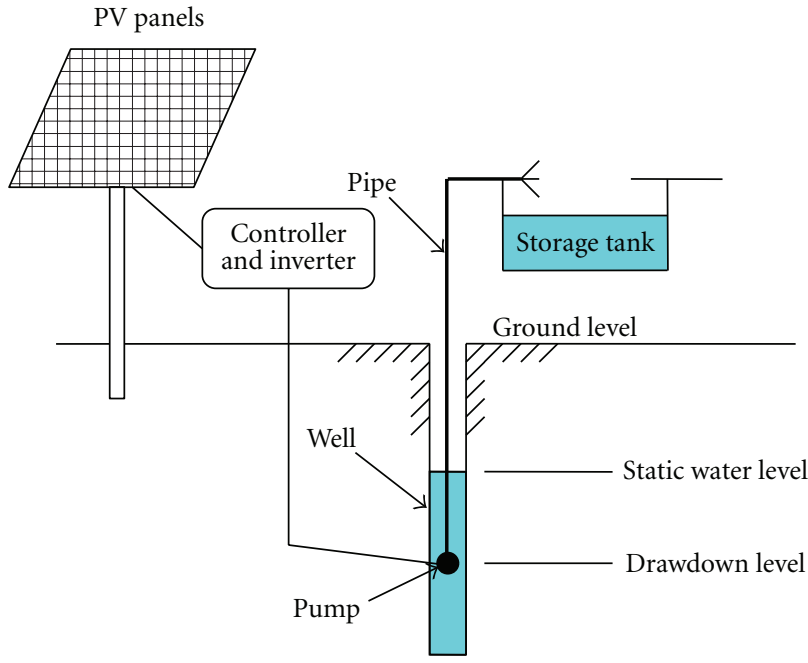

FIGURE 1: Schematic view of the solar photovoltaic water-pumping system.

operating life, inflation rate of $2 \%$, debt interest rate of $7.0 \%$, debt ratio of $70 \%$, and debt term of 10 years. The total capital cost was calculated to be US\$79,920, and it is assumed that it remains the same irrespective of location of the station. The total area covered by the PV panes was worked out to be $68 \mathrm{~m}^{2}$. The schematic view of the solar PV water-pumping system considered in this work is shown in Figure 1.

\section{Seasonal Variation of Solar Radiation on Horizontal Surface}

Long-term monthly average global solar radiation intensities on daily basis for Dhahran, Riyadh, Jeddah, Guriat, and Nejran are summarized in Table 2. Highest intensities of $7.73,7.87,7.95$, and $7.87 \mathrm{kWh} / \mathrm{m}^{2} / \mathrm{d}$ were observed in the month of June at Dhahran, Riyadh, Guriat, and Nejran, respectively and of $7.17 \mathrm{kWh} / \mathrm{m}^{2} / \mathrm{d}$ in May at Jeddah. It is also evident that relatively higher intensities were observed during April to September period which also correspond to higher-demand period for both power and water. Highest annual mean solar radiation intensity of $6.94 \mathrm{kWh} / \mathrm{m}^{2} / \mathrm{d}$ was found at Nejran.

\section{Solar Energy, Energy Density, and Greenhouse Gases Emission Analysis}

The energy produced a PV array and delivered to the grid is estimated as follows:

$$
E_{P}=S \eta_{P} \bar{H}_{t}
$$

where $S$ is the area of the array, $\bar{H}_{t}$ is the daily total radiation on tilted surface, and $\eta_{P}$ is the average efficiency of the PV array. The produced energy $\left(E_{P}\right)$ is reduced by taking into consideration the miscellaneous PV array losses, $\left(\lambda_{p}\right)$ and
TABLE 3: Values of PV module-related variables.

\begin{tabular}{lccc}
\hline PV module type & $\eta_{r}(\%)$ & NOCT $\left({ }^{\circ} \mathrm{C}\right)$ & $\beta_{P}\left(\% /{ }^{\circ} \mathrm{C}\right)$ \\
\hline Monocrystalline silicon (Mono-Si) & 13.0 & 45 & 0.40 \\
Polycrystalline silicon (Poly-Si) & 11.0 & 45 & 0.40 \\
Amorphous silicon (a-Si) & 5.0 & 50 & 0.11 \\
Cadmium telluride (CdTe) & 7.0 & 46 & 0.24 \\
Copper indium diselenide (CIS) & 7.5 & 47 & 0.46 \\
\hline
\end{tabular}

other power conditioning losses $\left(\lambda_{c}\right)$. These losses are taken into consideration using the following equation:

$$
E_{A}=E_{P}\left(1-\lambda_{p}\right)\left(1-\lambda_{c}\right)
$$

where $E_{A}$ is the PV array energy available to the load and the battery, if in use. The overall efficiency $\eta_{A}$ is defined as follows:

$$
\eta_{A}=\frac{E_{A}}{S \bar{H}_{t}} .
$$

In (1), the average efficiency of the PV array $\left(\eta_{P}\right)$ which is a function of average temperature of the PV module $T_{c}$ is estimated using the following equation:

$$
\eta_{P}=\eta_{r}\left[1-\beta_{P}\left(T_{c}-T_{r}\right)\right],
$$

where $\eta_{r}$ is the PV module efficiency at reference temperature $T_{r}\left(=25^{\circ} \mathrm{C}\right)$ and $\beta_{P}$ is the temperature coefficient for module efficiency. The module temperature $T_{c}$ is related to the mean monthly ambient temperature $T_{a}$ through Evan's [43] formula as given below:

$$
T_{c}-T_{a}=\left(219+832 \bar{K}_{t}\right)\left(\frac{\mathrm{NOCT}-20}{800}\right),
$$

where NOCT is the nominal operating cell temperature and $\bar{K}_{t}$ the monthly mean clearness index. The values of $\eta_{r}$, NOCT, $\beta_{P}$, and depend on the type of PV module considered. For standard technologies and module the values of these variables are summarized in Table 3 . The efficiency of photovoltaic cells varies with their operating temperature. Most cell types exhibit a decrease in efficiency as their temperature increases.

The monthly total energy estimated using (1) to (5) for all the locations is summarized in Table 4. This table also includes the energy density per unit area of the PV panel in $\mathrm{kWh} / \mathrm{m}^{2}$. At Dhahran and Riyadh the maximum energy of 1.569 and $1.596 \mathrm{MWh}$ was observed in the month of October while at Jeddah (1.573 MWh), Guriat $(1.517 \mathrm{MWh})$, and Nejran $(2.057 \mathrm{MWh})$ in the months of March, August, and November, respectively. Similarly, the highest values of energy density of 23.07, 23.47, 23.13, 22.31, and $30.25 \mathrm{kWh} / \mathrm{m}^{2}$ corresponding to Dhahran, Riyadh, Jeddah, Guriat, and Nejran occurred in the months of October, October, March, August, and November, respectively. Based on annual total energy output, maximum energy of 19.59 MWh was produced at Nejran while a minimum of 16.325 MWh at Dhahran, as can be seen from Table 4 . 
TABLe 4: Annual energy delivered and energy density for all the stations under consideration.

\begin{tabular}{lcccccccccc}
\hline \multirow{2}{*}{ Month } & \multicolumn{2}{c}{ Dhahran } & \multicolumn{2}{c}{ Riyadh } & \multicolumn{2}{c}{ Jeddah } & \multicolumn{2}{c}{ Guriat } & \multicolumn{2}{c}{ Nejran } \\
& MWh & $\mathrm{kWh} / \mathrm{m}^{2}$ & $\mathrm{MWh}$ & $\mathrm{kWh} / \mathrm{m}^{2}$ & $\mathrm{MWh}$ & $\mathrm{kWh} / \mathrm{m}^{2}$ & $\mathrm{MWh}$ & $\mathrm{kWh} / \mathrm{m}^{2}$ & $\mathrm{MWh}$ & $\mathrm{kWh} / \mathrm{m}^{2}$ \\
\hline Jan & 1.303 & 19.16 & 1.362 & 20.03 & 1.536 & 22.59 & 1.288 & 18.94 & 1.961 \\
Feb & 1.277 & 18.78 & 1.326 & 19.50 & 1.443 & 21.22 & 1.230 & 18.09 & 1.768 & 26.84 \\
Mar & 1.383 & 20.34 & 1.435 & 21.10 & 1.573 & 23.13 & 1.472 & 21.65 & 1.719 & 25.28 \\
Apr & 1.319 & 19.40 & 1.336 & 19.65 & 1.417 & 20.84 & 1.444 & 21.24 & 1.464 & 21.53 \\
May & 1.354 & 19.91 & 1.353 & 19.90 & 1.324 & 19.47 & 1.478 & 21.74 & 1.325 & 19.49 \\
Jun & 1.313 & 19.31 & 1.312 & 19.29 & 1.195 & 17.57 & 1.463 & 21.51 & 1.198 & 17.62 \\
Jul & 1.318 & 19.38 & 1.347 & 19.81 & 1.250 & 18.38 & 1.509 & 22.19 & 1.204 & 17.71 \\
Aug & 1.416 & 20.82 & 1.428 & 21.00 & 1.298 & 19.09 & 1.517 & 22.31 & 1.343 & 19.75 \\
Sep & 1.505 & 22.13 & 1.461 & 21.49 & 1.384 & 20.35 & 1.493 & 21.96 & 1.628 & 23.94 \\
Oct & 1.569 & 23.07 & 1.596 & 23.47 & 1.540 & 22.65 & 1.401 & 20.60 & 1.966 & 28.91 \\
Nov & 1.341 & 19.72 & 1.408 & 20.71 & 1.404 & 20.65 & 1.206 & 17.74 & 2.057 & 30.25 \\
Dec & 1.227 & 18.04 & 1.312 & 19.29 & 1.439 & 21.16 & 1.184 & 17.41 & 1.957 & 28.78 \\
\hline Annual & $\mathbf{1 6 . 3 2 5}$ & $\mathbf{2 4 0 . 0 7}$ & $\mathbf{1 6 . 6 7 7}$ & $\mathbf{2 4 5 . 2 5}$ & $\mathbf{1 6 . 8 0 4}$ & $\mathbf{2 4 7 . 1 2}$ & $\mathbf{1 6 . 6 8 5}$ & $\mathbf{2 4 5 . 3 7}$ & $\mathbf{1 9 . 5 9 0}$ & $\mathbf{2 8 8 . 0 9}$ \\
\hline
\end{tabular}

TABLE 5: Summary of greenhouse gases avoided as a result of PV power utilization for water pumping in Saudi Arabia at different locations.

\begin{tabular}{lcccc}
\hline Location & GHG $\left(\mathrm{tCO}_{2}\right)$ /year & Gasoline saved $(\mathrm{L} /$ year $)$ & \multicolumn{2}{c}{ During life time of the plant } \\
& & & $\mathrm{L}$ & 32.5 \\
Dhahran & 3.3 & 1,420 & 85.0 & 35,500 \\
Riyadh & 3.4 & 1,451 & 85.0 & 36,275 \\
Jeddah & 3.4 & 1,462 & 85.0 & 36,300 \\
Guriat & 3.4 & 1,452 & 100.0 & 42,600 \\
Nejran & 4.0 & 1,704 & $\mathbf{8 7 . 5}$ & $\mathbf{3 7 , 4 4 5}$ \\
\hline Average & $\mathbf{3 . 5}$ & $\mathbf{1 , 4 9 8}$ & & \\
\hline
\end{tabular}

As a result of utilization of solar energy for water pumping in Saudi Arabia, on an average of 3.5 tons of $\mathrm{CO}_{2}$ gas could be avoided from entering into the local atmosphere annually, as given in Table 5. Equivalently at Dhahran, Riyadh, Jeddah, Guriat, and Nejran a total of 1,420, $1,451,1,462,1,452$, and 1,704 liters of gasoline could be saved from burning for energy production annually. On an average, during the life time of the PV panels in operation, in this case 25 years, around 87.5 tons equivalent of green house gasses could be avoided from entering into the local atmosphere, or 37,445 liters of gasoline could be saved from burning.

\section{Economical Analysis of Solar Energy Production}

The pretax internal rate of return (IRR) on equity (\%) and assets (\%), which represents the true interest yield provided by the project equity and assets over its life before income tax, is calculated using the pre-tax yearly cash flows and the project life and included in Table 6. In the present case, IRR has been calculated on a nominal basis that is including inflation. For a project to be considered financially acceptable, IRR is expected to be equal to or greater than the required rate of return of the investor. The simple payback (year) is the duration of time that it takes for a proposed project to recoup its own initial cost, out of the income or savings it generates. The simple payback method is the indicator that how desirable is the investment. Lesser the payback period better will be the investment. From economical analysis, it is evident that Nejran is the best location for the utilization of PV solar energy with maximum internal rate of return (IRR) of $14.0 \%$ and plant capacity of $22.4 \%$ and minimum simple payback period of 9.7 years and cost of energy of $16.32 \mathrm{US} \$ / \mathrm{kWh}$ compared to other stations used in the present work. The other remaining locations are very near to each other whereas cost of energy and other economical indicators are concerned.

The effect of initial investment cost on cost of energy (COE) was also studied to check on the sensitivity. The initial investment costs of $8,7,6,5,4,3$, and 2US\$ per peak watt $\left(W_{p}\right)$ were considered while keeping all other interest rates the same. The resulting COE values for all the locations and initial investment rates are compared in Figure 2. It is evident that as the initial investment cost goes down, the COE also responds in the same manner. A decrease of US\$1 per $W_{p}$ in the initial investment cost (i.e., 7US\$ instead of 8 US\$) causes a decrease of $12.5 \%$ in COE (i.e., $17.13 \mathrm{US} \$ / \mathrm{kWh}$ instead of $19.58 \mathrm{US} \$ / \mathrm{kWh}$ ), and, for further decrease of 1US\$, the COE decreased to $14.69 \mathrm{US} \Phi / \mathrm{kWh}$ or a decrease of $16.7 \%$. 
TABLE 6: Summary of internal rate of return (IRR) and cost of energy (COE) for all the stations considered in the present work.

\begin{tabular}{lcccccc}
\hline \multirow{2}{*}{ Location } & \multicolumn{2}{c}{ Pretax IRR (\%) } & \multicolumn{2}{c}{ Payback period (years) } & Cost of energy (USథ/kWh) & \multirow{2}{*}{ Plant capacity factor (\%) } \\
& Equity & Assets & Simple & Equity & 19.582 & 18.7 \\
\hline Dhahran & 10.3 & 3.2 & 11.7 & 13.1 & 19.169 & 19.1 \\
Riyadh & 10.7 & 3.5 & 11.4 & 12.9 & 19.024 & 19.2 \\
Jeddah & 10.9 & 3.5 & 11.3 & 12.8 & 19.160 & 19.1 \\
Guriat & 10.7 & 3.5 & 11.4 & 12.9 & 16.319 & 22.4 \\
Nejran & 14.0 & 5.2 & 09.7 & 11.1 & $\mathbf{1 8 . 6 5 1}$ & $\mathbf{1 9 . 7}$ \\
\hline Average & $\mathbf{1 1 . 3}$ & $\mathbf{3 . 8}$ & $\mathbf{1 1 . 1}$ & $\mathbf{1 2 . 6}$ & \\
\hline
\end{tabular}

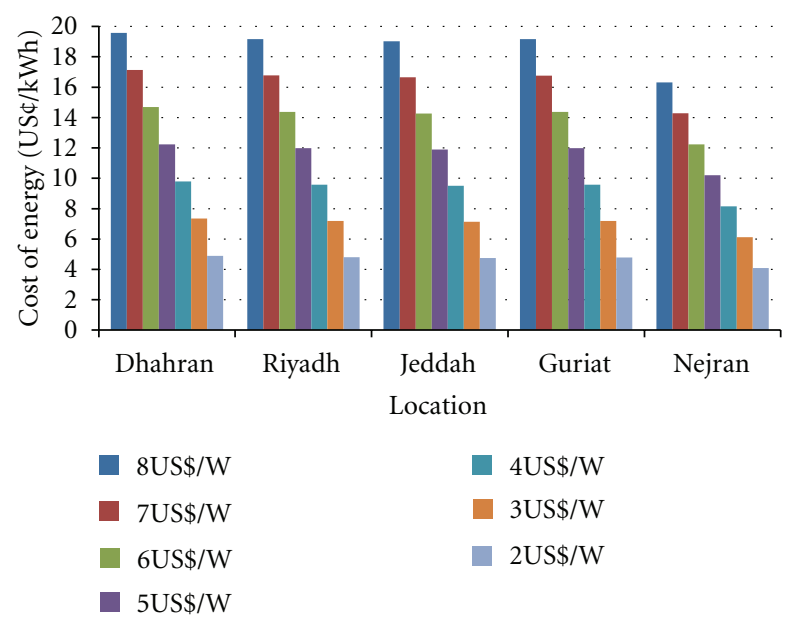

Figure 2: Effect of capital cost on cost of energy generated from $9.99 \mathrm{~kW}$ installed capacity PV power plant in Saudi Arabia.

\section{Performance of Solar-Energy-Based Water Pumping}

6.1. Water-Pumping Analysis. The power required for pumping water from underground $P_{h y d}(\mathrm{~W})$ can be determined by the expression

$$
P_{h y d}=\rho g H Q(\mathrm{~W})
$$

where $\rho$ is the density of water $\left(\mathrm{kg} / \mathrm{m}^{3}\right), g$ is the gravitational acceleration $\left(\mathrm{m} / \mathrm{s}^{2}\right), H$ is the total head $(m)$, and $Q$ is the volumetric flow rate of water $\left(\mathrm{m}^{3} / \mathrm{s}\right)$. Assuming that the density and the gravitational acceleration do not vary significantly, the product $H Q$ is found to be directly proportional to the pumping power requirement. $H Q$ may be considered as the pumping capacity rate. Thus the equation can be rewritten as

$$
H Q=\frac{P_{h y d}}{\rho g}\left(\mathrm{~m}^{4} / \mathrm{s}\right)
$$

to determine the pumping capacity rate HQ in $\mathrm{m}^{4} / \mathrm{s}$ for any given available power $P_{\text {hyd }}(\mathrm{W})$. Once the total head $H(\mathrm{~m})$ is available, the volumetric flow rate of water that can be pumped from underground $Q\left(\mathrm{~m}^{3} / \mathrm{s}\right)$ can be calculated. This expression indicates that a hydraulic power of $P_{\text {hyd }}=1 \mathrm{~W}$ is equivalent to a pumping capacity rate of $8.8 \mathrm{~m}^{4} /$ day. For

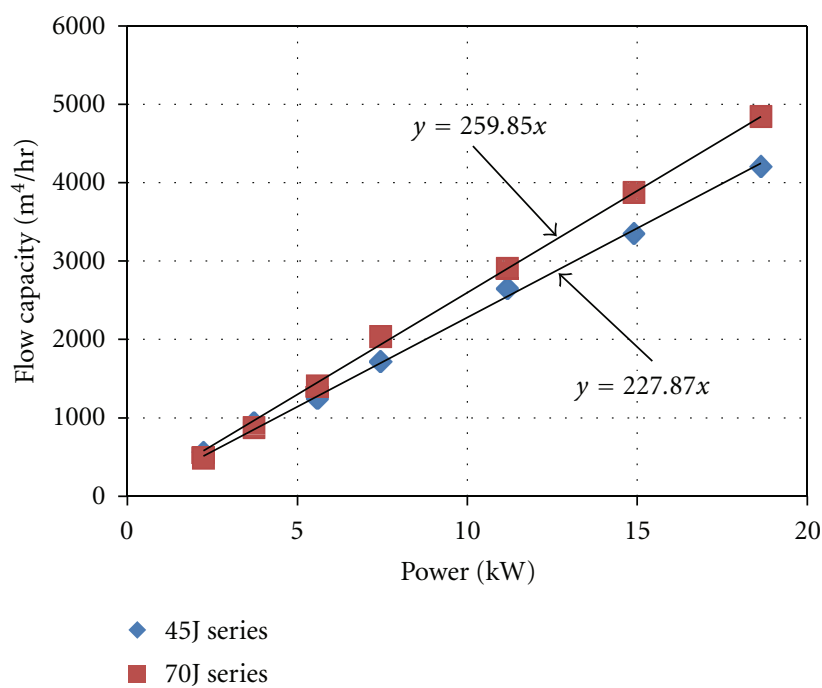

FIGURE 3: Flow capacity rate as function of pump size for two series of pumps.

the determination of the total pumping capacity for a given period of time, this equation can be written as

$$
H Q t=\frac{P_{h y d} \times t}{\rho g}\left(\mathrm{~m}^{4}\right),
$$

where time $t$ is time $(s)$. Accordingly, a hydraulic energy $\left(P_{\text {hyd }} \times t\right)$ of $1 \mathrm{kWh}$ (i.e., $\left.3600 \mathrm{~kJ}\right)$ is equivalent to a pumping capacity (HQt) of $367 \mathrm{~m}^{4}$. On the other hand, the required pump size $\mathrm{P}(\mathrm{W})$ can be determined from

$$
P=\frac{P_{h y d}}{\eta}=\frac{\rho g H Q}{\eta}
$$

where $\eta$ is the pump efficiency.

6.2. Water-Pumping Capacity. Twelve models of water pumps at different sizes from Goulds Pump Company were selected in the present work. Six of these are from 45J series, and the remaining six are from 70J series high-capacity flat bowl 6-inch submersible pumps. Detail specifications of these pumps are given in Tables 7(a) and 7(b). The nominal flow rate of these pumps at best efficiency ranges from 45 to $70 \mathrm{GPM}$, and their motor size ranges from 3 to $25 \mathrm{HP}$. Depth of water for which the pumps operate ranges from 


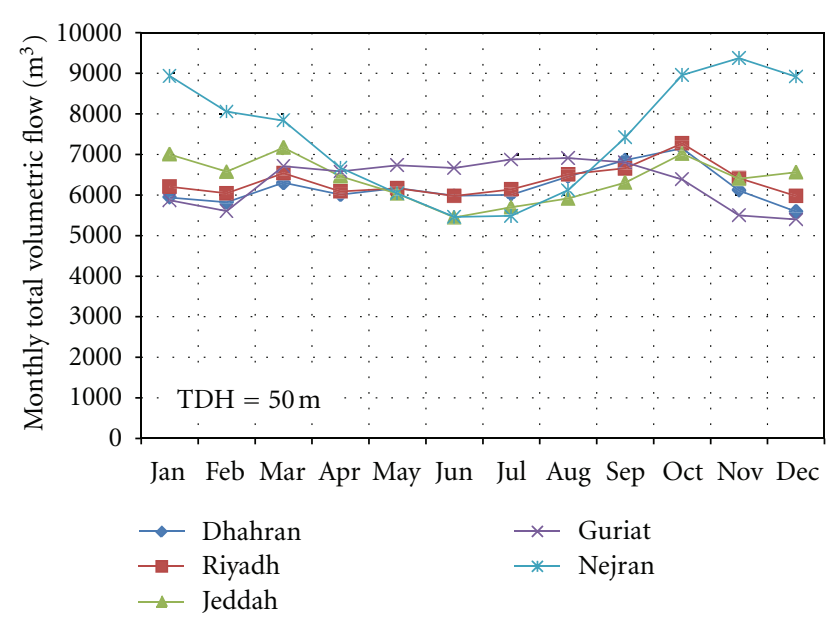

Figure 4: Monthly total volumetric flow of water from a well with total dynamic head of $50 \mathrm{~m}$ using solar PV-operated Goulds model 45J series pump for five different sites in Saudi Arabia.

100 to 1350 feet. Nominal flow capacity rate of each pump (in $\mathrm{m}^{4} / \mathrm{hr}$ ) is also given in the last column in Table 7 .

Figure 3 shows the nominal flow capacity rate variation of the pumps at best efficiency point as function of the power consumption. As can be seen from this figure, the nominal flow capacity rate is almost linear with the power (or size) of the pump in each series of pumps. The least squares fit line for the data is shown on the figure for each series. The slopes of the lines are slightly different from each other as a result of different efficiencies of pumps. 70J series pumps are slightly more efficient $(62 \% \mathrm{max})$ than the $45 \mathrm{~J}$ series pumps $(60 \%$ $\max$ ). Accordingly, the relationship of nominal flow capacity rate and the power for each series of pumps can be expressed as follows:

Flow capacity rate $\left(\mathrm{m}^{4} / \mathrm{hr}\right)=227.87 \times$ Power $(\mathrm{kW})$ for $45 \mathrm{~J}$ series

Flow capacity rate $\left(\mathrm{m}^{4} / \mathrm{hr}\right)=259.85 \times$ Power $(\mathrm{kW})$ for $70 \mathrm{~J}$ series.

The flow rate in $\mathrm{m}^{3} / \mathrm{hr}$ is obtained by dividing the flow capacity rate with the total dynamic head (TDH).

Monthly total volumetric flow of water from a depth of $50 \mathrm{~m}$ total dynamic head using solar PV-operated Goulds model 45J series pumps is shown in Figure 4. The maximum efficiency of the pumps in this series is $60 \%$. Monthly total volumetric flow of water shows fairly uniform variation throughout the year except for the Nejran site. In Nejran site the volumetric flow is found to be considerably higher during the winter months as compared with that during the summer months. This is due to the high solar energy availability during the winter months in the site of Najran. Referring to Table 4, the yearly average solar electric power generation from the solar PV panels considered in the five sites, namely, Dhahran, Riyad, Jeddah, Guriat, and Nejran is $1.86,1.90,1.92,1.90$, and $2.24 \mathrm{~kW}$, respectively. Therefore the most suitable pump model for the solar PV energy generator is the 45J03 model that comes with $5 \mathrm{hp}(2.24 \mathrm{~kW})$ motor

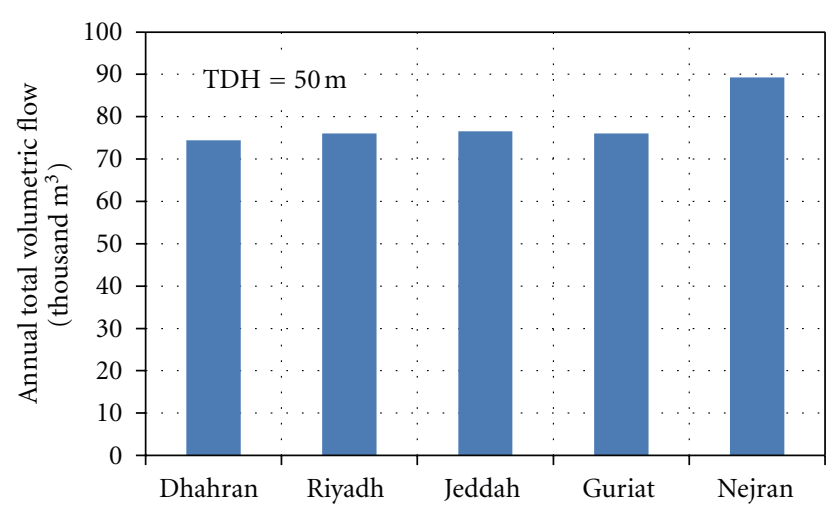

FIGURE 5: The annual total volumetric flow of water from a well with total dynamic head of $50 \mathrm{~m}$ using solar PV-operated Goulds model 45J series pump for five different sites in Saudi Arabia.

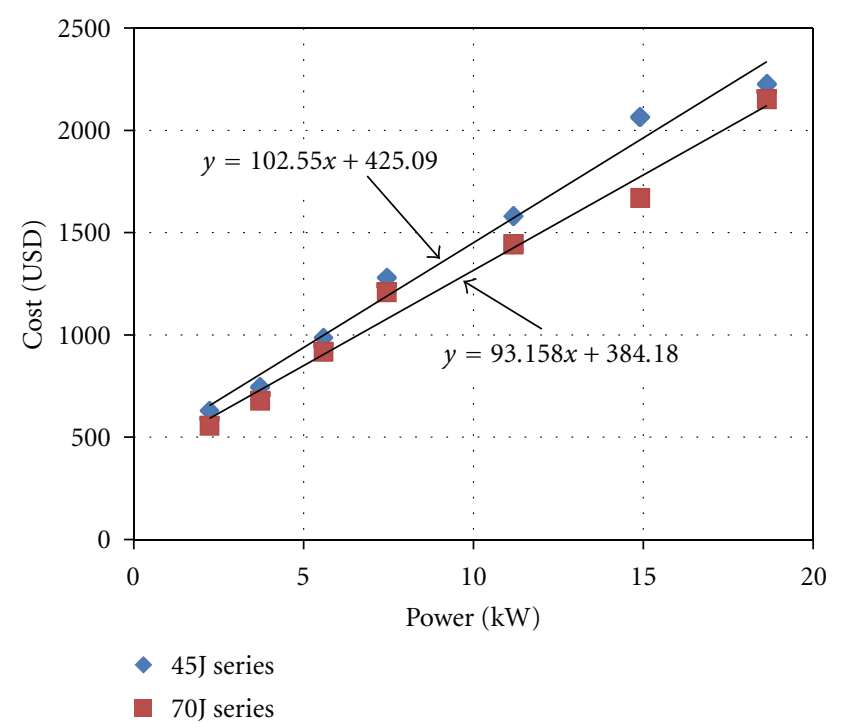

Figure 6: Cost of pumps as function of the pump size (power) for two series of pumps.

and efficiently operates with a TDH of $54.58 \mathrm{~m}$ as can be seen from Table 7(a). This is the reason why the TDH is fixed to be $50 \mathrm{~m}$ in Figure 4 . The annual total volumetric flow of water for the same solar PV energy generator is shown in Figure 5 for the five sites considered. The variation of the annual total volumetric flow among the sites considered is minimal except for the case of Nejran site where the annual total volumetric flow is about $18 \%$ more than the other sites.

Figure 6 shows the cost (price) of water pumps considered in this study. The price of water pumps is found to increase with the size of the pumps. The variation shows a nearly linear trend for both series of pumps considered. This trend can be expressed in first-order approximation for both the pump series as

Price $(\$)=102.55 \times$ Power $(\mathrm{kW})+425.09$ for $45 \mathrm{~J}$ series

Price $(\$)=93.158 \times$ Power $(\mathrm{kW})+384.18$ for $70 \mathrm{~J}$ series of pumps. 
TABLE 7

(a) Specifications of Goulds water pumps 45J series considered

\begin{tabular}{|c|c|c|c|c|c|c|c|c|}
\hline Model & Price (USD) & Flow rate (GPM) & Power (hp) & TDH (feet) & Flow rate $\left(\mathrm{m}^{3} / \mathrm{hr}\right)$ & Power $(\mathrm{kW})$ & $\mathrm{TDH}(\mathrm{m})$ & Flow capacity rate $\left(\mathrm{m}^{4} / \mathrm{hr}\right)$ \\
\hline $45 \mathrm{~J} 03$ & 630 & 45 & 3 & 180 & 10.22175 & 2.2368 & 54.864 & 560.8061 \\
\hline $45 \mathrm{~J} 05$ & 745 & 45 & 5 & 300 & 10.22175 & 3.728 & 91.44 & 934.6768 \\
\hline $45 \mathrm{~J} 07$ & 987 & 45 & 7.5 & 400 & 10.22175 & 5.592 & 121.92 & 1246.236 \\
\hline $45 \mathrm{~J} 10$ & 1280 & 45 & 10 & 550 & 10.22175 & 7.456 & 167.64 & 1713.574 \\
\hline $45 \mathrm{~J} 15$ & 1580 & 45 & 15 & 850 & 10.22175 & 11.184 & 259.08 & 2648.251 \\
\hline $45 \mathrm{~J} 20$ & 2065 & 45 & 20 & 1075 & 10.22175 & 14.912 & 327.66 & 3349.259 \\
\hline $45 \mathrm{~J} 25$ & 2226 & 45 & 25 & 1350 & 10.22175 & 18.64 & 411.48 & 4206.046 \\
\hline
\end{tabular}

Data at best efficiency $(\% 60)$.

(b) Specifications of Goulds water pumps 70J series considered

\begin{tabular}{lcccccccc}
\hline Model & Price (USD) & Flow rate $(\mathrm{GPM})$ & Power $(\mathrm{hp})$ & $\mathrm{TDH}(\mathrm{feet})$ & Flow rate $\left(\mathrm{m}^{3} / \mathrm{hr}\right)$ & Power $(\mathrm{kW})$ & $\mathrm{TDH}(\mathrm{m})$ & Flow capacity rate $\left(\mathrm{m}^{4} / \mathrm{hr}\right)$ \\
\hline 70J03 & 556 & 70 & 3 & 100 & 15.9005 & 2.2368 & 30.48 & 484.6472 \\
$70 \mathrm{~J} 05$ & 680 & 70 & 5 & 180 & 15.9005 & 3.728 & 54.864 & 872.365 \\
$70 \mathrm{~J} 07$ & 919 & 70 & 7.5 & 290 & 15.9005 & 5.592 & 88.392 & 1405.477 \\
$70 \mathrm{~J} 10$ & 1208 & 70 & 10 & 420 & 15.9005 & 7.456 & 128.016 & 2035.518 \\
$70 \mathrm{~J} 15$ & 1443 & 70 & 15 & 600 & 15.9005 & 11.184 & 182.88 & 2907.883 \\
$70 \mathrm{~J} 20$ & 1670 & 70 & 20 & 800 & 15.9005 & 14.912 & 243.84 & 3877.178 \\
$70 \mathrm{~J} 25$ & 2152 & 70 & 25 & 1000 & 15.9005 & 18.64 & 304.8 & 4846.472 \\
\hline
\end{tabular}

Data at best efficiency (\%62).

TABle 8: Cost of solar PV water pumping from a well with $50 \mathrm{~m}$ TDH.

\begin{tabular}{lc}
\hline Location & Cost of water pumping with $\mathrm{TDH}=50 \mathrm{~m}\left(\mathrm{US} \ / \mathrm{m}^{3}\right)$ \\
\hline Dhahran & 2.69 \\
Riyadh & 2.63 \\
Jeddah & 2.61 \\
Guriat & 2.63 \\
Nejran & 2.24 \\
\hline Average & $\mathbf{2 . 5 6}$ \\
\hline
\end{tabular}

Considering both of the relationships, a representative linear relation applicable for all the pump can be obtained by

$$
\text { Price }(\$)=98 \times \operatorname{Power}(\mathrm{kW})+405 \text {. }
$$

Considering the pump model 45J03, a cost of USD630 is added to the capital cost of solar PV system. Therefore the cost of water produced from a well of $50 \mathrm{~m}$ TDH becomes $2.69,2.63,2.61,2.63$, and $2.24 \mathrm{US} థ / \mathrm{m}^{3}$ for Dhahran, Riyadh, Jeddah, Guriat, and Nejran, respectively, as shown in Table 8. The average pumping cost of water per cubic meter is found to be 2.56 US 4 .

\section{Conclusions}

An economical feasibility study was carried out in relation to producing electrical energy using PV solar panels for pumping underground water at Dhahran, Riyadh, Jeddah, Guriat, and Nejran sites in Saudi Arabia. A solar PV energy generation system producing $9.99 \mathrm{~kW}$ of electrical energy was considered. The electrical energy generated was used to calculate the underground water-pumping capacity at each of the five sites. The following conclusions can be derived from the present work.

(i) The annual total energy output was found to be the maximum (19.59 MWh) at Nejran site while it was a minimum (16.325 MWh) at Dhahran site.

(ii) The Nejran site was found to be most economical in terms of minimal payback period and cost of energy and maximum internal rate of return.

(iii) Goulds model 45J series of pumps were found to be suitable to be integrated with the solar PV energy generation system.

(iv) Based on the solar PV electrical energy generation, monthly total water-pumping capacities were found to be nearly uniform throughout the year except for the Nejran site. Considerably higher water production capacity was observed during the winter months in Nejran.

(v) Annual total water-pumping capacities were almost equal in all the sites considered except for the Nejran site where the water-pumping capacity was \%18 higher.

(vi) The cost analysis of water pumping system indicated that, for a well of $50 \mathrm{~m}$ total dynamic head (TDH), the cost of water pumping vary between 2 and $3 \mathrm{US} \$ / \mathrm{m}^{3}$ in all the five sites in Saudi Arabia. 


\section{Acknowledgment}

The authors would like to acknowledge the support provided by King Abdulaziz City for Science and Technology (KACST) through the Science and Technology Unit at King Fahd University of Petroleum and Minerals (KFUPM) for funding this work through project no. 09-ENE779-04 as part of the National Science, Technology and Innovation Plan.

\section{References}

[1] S. Rehman, M. A. Bader, and S. A. Al-Moallem, "Cost of solar energy generated using PV panels," Renewable and Sustainable Energy Reviews, vol. 11, no. 8, pp. 1843-1857, 2007.

[2] W. Bucher, "Aspects of solar water pumping in remote regions," Energy for Sustainable Development, vol. 3, no. 4, pp. 8-27, 1996.

[3] R. Barlow, B. McNeils, and A. Derrick, "Solar pumping: an introduction and update on the technology, performance, costs, and economics," World Bank technical paper no.168, Intermediate technology publications and the World Bank, Washington, DC, USA, 1993.

[4] A. J. van Staden, J. Zhang, and X. Xia, "A model predictive control strategy for load shifting in a water pumping scheme with maximum demand charges," Applied Energy, vol. 8, pp. 4785-4794, 2011.

[5] S. Sallem, M. Chaabene, and M. B. A. Kamoun, "Energy management algorithm for an optimum control of a photovoltaic water pumping system," Applied Energy, vol. 86, no. 12, pp. 2671-2680, 2009.

[6] Z. Şen and Ş. M. Cebeci, "Solar irradiation estimation by monthly principal component analysis," Energy Conversion \& Management, vol. 49, no. 11, pp. 3129-3134, 2008.

[7] M. Xu, R. V. N. Melnik, and U. Borup, "Modeling antiislanding protection devices for photovoltaic systems," Renewable Energy, vol. 29, no. 15, pp. 2195-2216, 2004.

[8] H. Kawamura, K. Naka, N. Yonekura et al., "Simulation of IV characteristics of a PV module with shaded PV cells," Solar Energy Materials and Solar Cells, vol. 75, no. 3-4, pp. 613-621, 2003.

[9] M. C. Fedrizzi, F. S. Ribeiro, and R. Zilles, "Lessons from field experiences with photovoltaic pumping systems in traditional communities," Energy for Sustainable Development, vol. 13, no. 1, pp. 64-70, 2009.

[10] D. B. Nelson, M. H. Nehrir, and C. Wang, "Unit sizing and cost analysis of stand-alone hybrid wind/PV/fuel cell power generation systems," Renewable Energy, vol. 31, no. 10, pp. 1641-1656, 2006.

[11] A. Hamidat and B. Benyoucef, "Mathematic models of photovoltaic motor-pump systems," Renewable Energy, vol. 33, no. 5, pp. 933-942, 2008.

[12] X. Gong and M. Kulkarni, "Design optimization of a large scale rooftop photovoltaic system," Solar Energy, vol. 78, no. 3, pp. 362-374, 2005.

[13] M. S. S. Ashhab, "Optimization and modeling of a photovoltaic solar integrated system by neural networks," Energy Conversion \& Management, vol. 49, no. 11, pp. 3349-3355, 2008.

[14] W. De Soto, S. A. Klein, and W. A. Beckman, "Improvement and validation of a model for photovoltaic array performance," Solar Energy, vol. 80, no. 1, pp. 78-88, 2006.
[15] A. H. Arab, F. Chenlo, K. Mukadam, and J. L. Balenzategui, "Performance of PV water pumping systems," Renewable Energy, vol. 18, no. 2, pp. 191-204, 1999.

[16] J. S. Ramos and H. M. Ramos, "Solar powered pumps to supply water for rural or isolated zones: a case study," Energy for Sustainable Development, vol. 13, no. 3, pp. 151-158, 2009.

[17] S. Ould-Amrouche, D. Rekioua, and A. Hamidat, "Modelling photovoltaic water pumping systems and evaluation of their $\mathrm{CO}_{2}$ emissions mitigation potential," Applied Energy, vol. 87, no. 11, pp. 3451-3459, 2010.

[18] E. Mahmoud and H. El-Nather, "Renewable energy and sustainable developments in Egypt: photovoltaic water pumping in remote areas," Applied Energy, vol. 74, no. 1-2, pp. 141-147, 2003.

[19] J. K. Kaldellis, E. Meidanis, and D. Zafirakis, "Experimental energy analysis of a stand-alone photovoltaic-based water pumping installation," Applied Energy, vol. 88, pp. 4556-4562, 2011.

[20] A. G. Bhave, "Potential for solar water-pumping systems in India," Applied Energy, vol. 48, no. 3, pp. 197-200, 1994.

[21] S. Alawaji, M. S. Smiai, S. Rafique, and B. Stafford, "PVpowered water pumping and desalination plant for remote areas in Saudi Arabia," Applied Energy, vol. 52, no. 2-3, pp. 283-289, 1995.

[22] M. A. Hammad, "Characteristics of solar water pumping in Jordan," Energy, vol. 24, no. 2, pp. 85-92, 1999.

[23] Z. Al Suleimani and N. R. Rao, "Wind-powered electric water-pumping system installed in a remote location," Applied Energy, vol. 65, no. 1, pp. 339-347, 2000.

[24] A. Al-Karaghouli and A. M. Al-Sabounchi, "A PV pumping system," Applied Energy, vol. 65, no. 1-4, pp. 145-151, 2000.

[25] D. Manolakos, G. Papadakis, D. Papantonis, and S. Kyritsis, "A stand-alone photovoltaic power system for remote villages using pumped water energy storage," Energy, vol. 29, no. 1, pp. 57-69, 2004.

[26] M. Kordab, "Priority option of photovoltaic systems for water pumping in rural areas in ESCWA member countries," Desalination, vol. 209, no. 1-3, pp. 73-77, 2007.

[27] K. Meah, S. Fletcher, and S. Ula, "Solar photovoltaic water pumping for remote locations," Renewable and Sustainable Energy Reviews, vol. 12, no. 2, pp. 472-487, 2008.

[28] K. Sutthivirode, P. Namprakai, and N. Roonprasang, "A new version of a solar water heating system coupled with a solar water pump," Applied Energy, vol. 86, no. 9, pp. 1423-1430, 2009.

[29] F. J. Chueco-Fernández and A. Bayod-Rújula, "Power supply for pumping systems in northern Chile: photovoltaics as alternative to grid extension and diesel engines," Energy, vol. 35, no. 7, pp. 2909-2921, 2010.

[30] S. Rehman and M. Mohandes, "Estimation of diffuse fraction of global solar radiation using artificial neural networks," Energy Sources A, vol. 31, no. 11, pp. 974-984, 2009.

[31] S. Rehman and M. Mohandes, "Artificial neural network estimation of global solar radiation using air temperature and relative humidity," Energy Policy, vol. 36, no. 2, pp. 571-576, 2008.

[32] S. Rehman and T. O. Halawani, "Global solar radiation estimation,” Renewable Energy, vol. 12, no. 4, pp. 369-385, 1997.

[33] S. Rehman and T. O. Halawani, "Development and utilization of solar energy in Saudi Arabia-review," Arabian Journal for Science and Engineering, vol. 23, no. 1, pp. 33-46, 1998. 
[34] S. Rehman, "Solar radiation over Saudi Arabia and comparisons with empirical models," Energy, vol. 23, no. 12, pp. 10771082, 1998.

[35] M. Mohandes, S. Rehman, and T. O. Halawani, "Estimation of global solar radiation using artificial neural networks," Renewable Energy, vol. 14, no. 1-4, pp. 179-184, 1998.

[36] S. Rehman, "Empirical model development and comparison with existing correlations," Applied Energy, vol. 64, no. 1-4, pp. 369-378, 1999.

[37] S. Rehman and S. G. Ghori, "Spatial estimation of global solar radiation using geostatistics," Renewable Energy, vol. 21, no. 3-4, pp. 583-605, 2000.

[38] S. Rehman, M. A. Bader, and S. A. Al-Moallem, "Cost of solar energy generated using PV panels," Renewable and Sustainable Energy Reviews, vol. 11, no. 8, pp. 1843-1857, 2007.

[39] A. Aksakal and S. Rehman, "Global solar radiation in Northeastern Saudi Arabia," Renewable Energy, vol. 17, no. 4, pp. 461-472, 1999.

[40] S. Rehman, A. A. Shash, and O. S. B. Al-Amoudi, "Photovoltaic technology of electricity generation for desert camping," International Journal of Global Energy Issues, vol. 26, no. 3-4, pp. 322-340, 2006.

[41] A. R. Al-Ali, S. Rehman, S. Al-Agili, M. H. Al-Omari, and M. Al-Fayezi, "Usage of photovoltaics in an automated irrigation system," Renewable Energy, vol. 23, no. 1, pp. 17-26, 2001.

[42] M. Mohandes and S. Rehman, "Global solar radiation maps of Saudi Arabia," Journal of Energy and Power Engineering, vol. 4, no. 12, pp. 57-63, 2010.

[43] D. L. Evans, "Simplified method for predicting photovoltaic array output," Solar Energy, vol. 27, no. 6, pp. 555-560, 1981. 


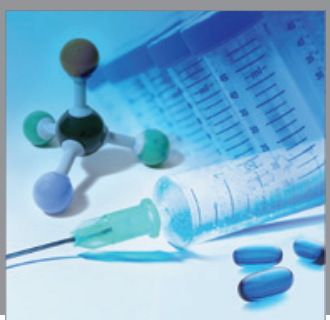

International Journal of

Medicinal Chemistry

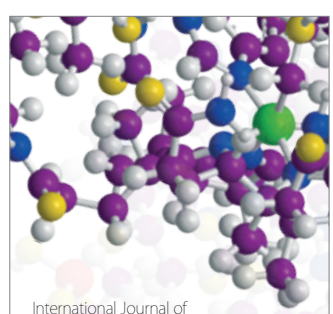

Carbohydrate Chemistry

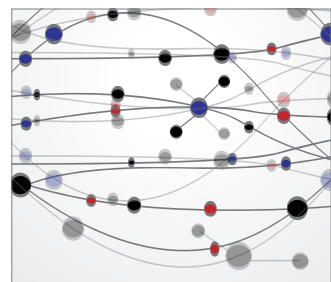

The Scientific World Journal
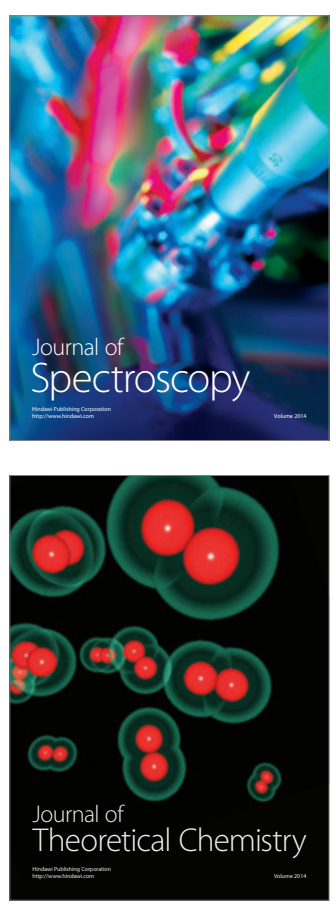
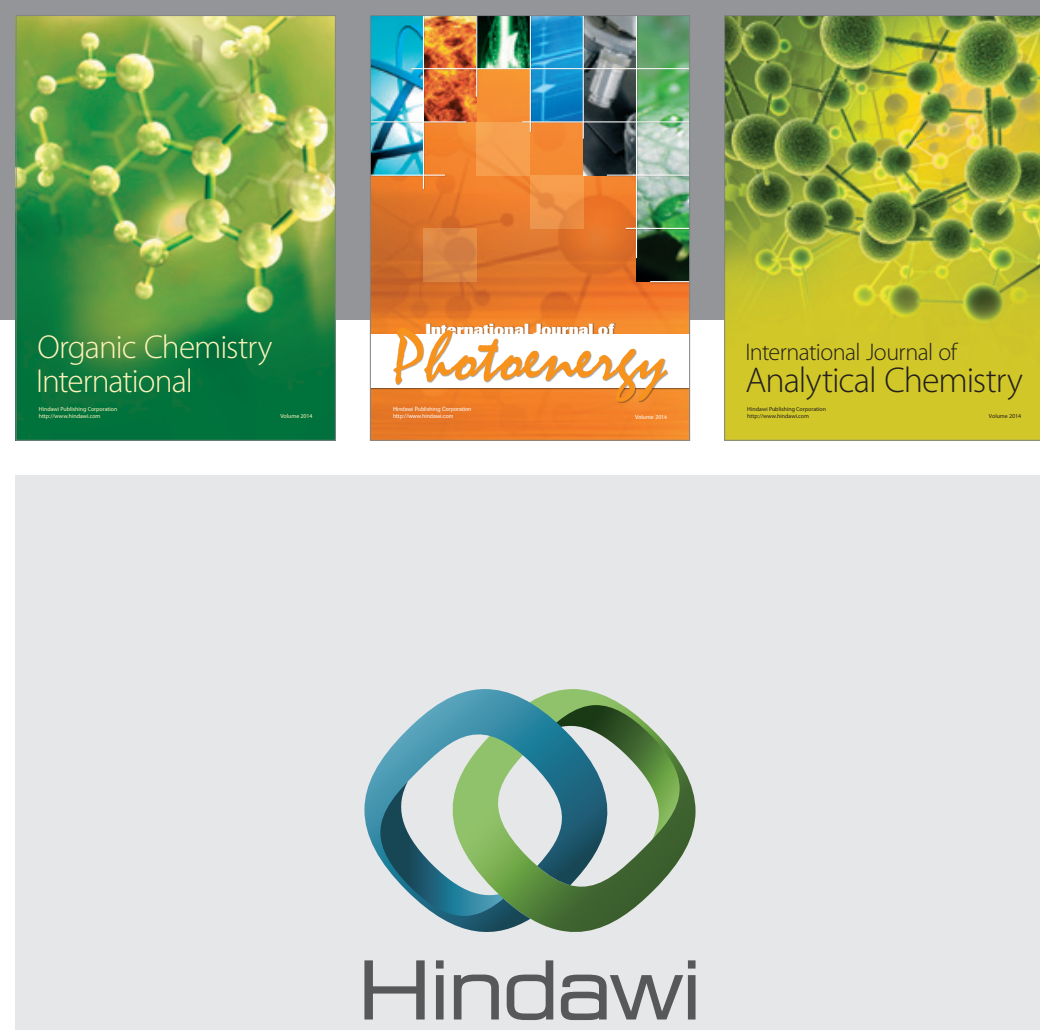

Submit your manuscripts at

http://www.hindawi.com
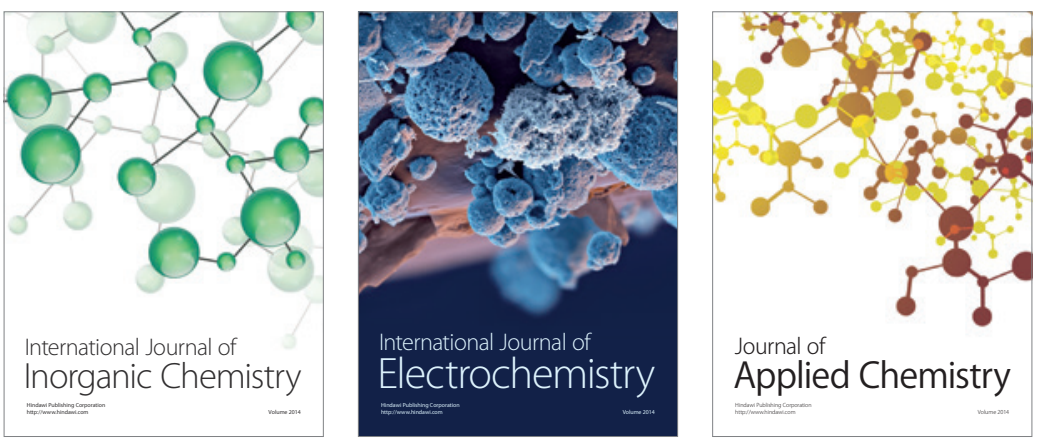

Journal of

Applied Chemistry
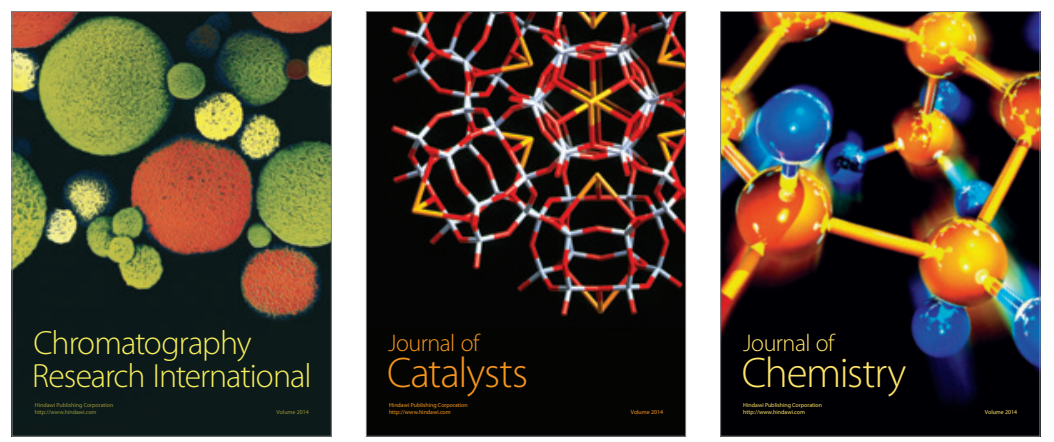
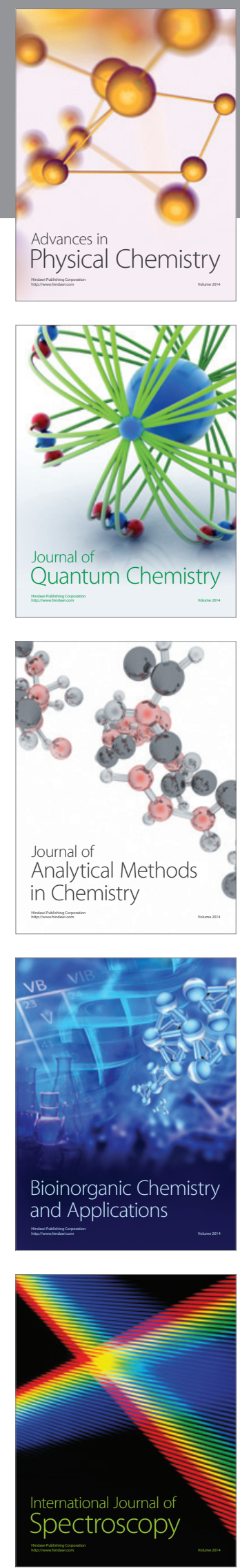